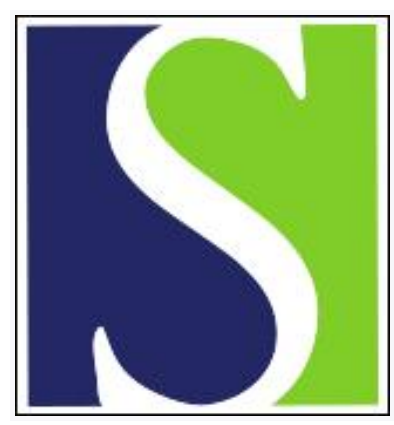

Scand J Work Environ Health 1980;6(3):201-205

https://doi.org/10.5271/sjweh.2615

Issue date: Sep 1980

A pilot study on respiratory and digestive tract cancer among woodworkers.

by Esping B, Axelson $O$

Key terms: cancer; case-control study; case-referent study; digestive tract cancer; furniture; occupation; occupational cancer; pilot study; respiratory cancer; wood; woodworker

This article in PubMed: www.ncbi.nlm.nih.gov/pubmed/6937825

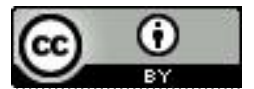




\title{
A pilot study on respiratory and digestive tract cancer among woodworkers
}

\author{
by Bengt Esping, MD, ' Olav Axelson, MD ${ }^{2}$
}

\begin{abstract}
ESPING B, AXELSON O. A pilot study on respiratory and digestive tract cancer among woodworkers. Scand $j$ work environ health 6 (1980) 201-205. Cancer of the nose and paranasal sinuses is a known occupational hazard among workers in the furniture industry. An increased frequency of cancer at other sites has also been suggested to occur among different types of woodworkers in the United States, eg, cancer of the gastrointestinal tract and lung but also lymphatic and hematopoietic malignancies. This case-referent study is of a pilot character and was undertaken for the further elucidation of respiratory and digestive tract cancer among Swedish woodworkers. A fourfold excess of respiratory cancer, other than nasal cancer, was found, particularly in relation to furniture workers, whereas no definite excess of digestive tract cancer was indicated. Further studies seem worthwhile regarding cancer hazard in the woodworking industry.
\end{abstract}

Key terms: case-control, case-referent, furniture, occupation, occupational cancer, wood.

Cancer of the nose and paranasal sinuses is a known occupational hazard among workers in the furniture industry. The first reports appeared in England in the 1960 s $(1,2,13)$, and similar findings were made in the Netherlands (6) and France (9). Consistent observations have followed from many other countries, eg, Denmark (19), Australia (11), the United States (5), Sweden (8), and the German Democratic Republic (12). Thus the risk of nasal cancer among furniture makers seems to be fairly well established.

However, an increased frequency of cancer has also been reported for other sites in woodworkers. Plywood mill workers showed an increased mortality from cancer of the stomach and of the lymphatic and hematopoietic tissues (eg, multiple myeloma, myeloid and acute leukemia)

1 Industrial Health Care Unit, Mjölby, Sweden.

2 Department of Occupational Medicine, University Hospital, Linköping, Sweden.

Reprint requests to: Prof Olav Axelson, Department of Occupational Medicine, University Hospital, S-581 85 Linköping, Sweden.
(18), and similar observations were made among pulp and paper workers, who also showed an excess of cancer of the small intestine. The same study indicated an excess of stomach cancer, Hodgkin's disease, and slightly increased numbers of multiple myelomas and leukemias among carpenters.

Exposure to wood dust has been suggested as an etiologic factor for nasal cancer and may also explain the appearance of an excess of gastrointestinal cancer since a fraction of the dust deposited in the respiratory tract is eventually swallowed. An etiologic mechanism for lymphatic and hematopoietic malignancies is more difficult to detect however.

If dust exposure is assumed to play an etiologic role in cancer hazard, also lung cancer should be expected to appear somewhat excessively among woodworkers. An observation of increased lung cancer morbidity among employees of the wood and paper industry in rural counties of Georgia in the United States (10) may be interpreted as supporting this assumption. Further studies in various countries 
are obviously desirable to elucidate the cancer morbidity pattern among woodworkers more fully. Therefore, this pilot study with a case-referent (case-control) design was undertaken in a small Swedish town (Mjölby, 13,000 inhabitants in 1979) with a comparatively large woodworking industry, particularly in furniture production. The town also has other industries, including metal manufacturing, food and chemical industries and various other small enterprises, and it thus provides a background of mixed exposure for its population. Under such circumstances, the case-referent study is a suitable and convenient approach (4) and may also be more sensitive than a traditional cohort with national rates as the reference.

\section{Subjects and methods}

The study considers respiratory cancer and cancer of the digestive tract. Subjects for the study, cases as well as referents (controls), were obtained from the local register of deaths and burials in the town parish during the period 1963-1977. Only men 50 a of age or older were enrolled, younger ages providing little information due to lack of cases.

\section{Subject selection}

The diagnoses of respiratory cancer (ICD $1965,160-163)$ and digestive tract cancer (the mouth included) (ICD 1965, 140-159) were chosen as the cases, ie, the study comprises two different case entities. If a cancer of the specific types under study was mentioned among the death diagnoses, the cancer diagnosis was always considered to be the underlying cause of death Referents were those male individuals who had entered the register in the two positions before and after each case. It should be pointed out that local registers of deaths and burials have a high quality in Sweden and usually provide the complete diagnoses, as taken from the death certificates (7).

The occupational titles in the register were used as the measure of exposure in the study. Some individuals had only the title woodworker; for others there was an occupational title which specifically indicated employment in the furniture industry. Although this exposure classification is somewhat crude, it may be emphasized, for reasons of validity, that the registration of occupational titles should be expected to be similar among both the cases and referents, ie, the results of the study might well be somewhat imprecise but not biased. Furthermore, a less specific occupational title, or "exposure," would tend to decrease any differences between cases and referents, making the study conservative.

\section{Statistical methods}

Statistical analyses of the data were based on the Mantel-Haenszel procedures (14). The principles applied for the determination of the standardized rate ratios have

Table 1. Distribution of cases among woodworkers and other occupations with regard to age and group of diagnoses.

\begin{tabular}{|c|c|c|c|c|c|}
\hline \multicolumn{3}{|c|}{ Woodworkers } & \multicolumn{3}{|c|}{ Other occupations } \\
\hline \multirow{2}{*}{$\begin{array}{l}\text { Diagnosis and } \\
\text { ICD number }\end{array}$} & \multicolumn{2}{|c|}{ Age (a) } & \multirow{2}{*}{$\begin{array}{l}\text { Diagnosis and } \\
\text { ICD number }\end{array}$} & \multicolumn{2}{|c|}{ Age (a) } \\
\hline & $50-69$ & $\geq 70$ & & $50-69$ & $\geq 70$ \\
\hline $\begin{array}{l}\text { Mouth and pharynx } \\
140-149\end{array}$ & 0 & 0 & $\begin{array}{l}\text { Mouth and pharynx } \\
140-149\end{array}$ & 1 & 1 \\
\hline $\begin{array}{l}\text { Digestive tract } \\
150-159\end{array}$ & 1 & 5 & $\begin{array}{l}\text { Digestive tract } \\
150-159\end{array}$ & 20 & 42 \\
\hline $\begin{array}{l}\text { Respiratory system } \\
160-163\end{array}$ & 2 & 4 & $\begin{array}{l}\text { Respiratory system } \\
160-163\end{array}$ & 10 & 9 \\
\hline Total & 3 & 9 & & 31 & 52 \\
\hline
\end{tabular}


Table 2. Exposure to woodwork among cases of respiratory cancer (ICD $160-163$ ) and among cases with cancer of the mouth or digestive tract (ICD 140-159) and among referents having died in the parish in question in 1963-1977.

\begin{tabular}{|c|c|c|c|c|}
\hline \multirow{2}{*}{$\begin{array}{l}\text { Age } \\
\text { (a) }\end{array}$} & \multicolumn{2}{|c|}{ Respiratory cancer } & \multicolumn{2}{|c|}{$\begin{array}{l}\text { Mouth and digestive } \\
\text { tract cancer }\end{array}$} \\
\hline & Nonexposed & Exposed & Nonexposed & Exposed \\
\hline \multicolumn{5}{|l|}{$50-69$} \\
\hline Case & 10 & 2 & 21 & 1 \\
\hline Referent & 107 & 7 & 107 & 7 \\
\hline \multicolumn{5}{|l|}{$\geq 70$} \\
\hline Case & 9 & 4 & 43 & 5 \\
\hline Referent & 235 & 21 & 235 & 21 \\
\hline \multicolumn{2}{|c|}{ Crude rate ratio } & 3.9 & & 1.1 \\
\hline \multicolumn{2}{|c|}{ Standard mortality ratio } & 4.1 & & 1.2 \\
\hline \multicolumn{5}{|c|}{ Mantel-Haenszel rate ratio } \\
\hline - point & intonget & 4.1 & & 1.1 \\
\hline$-95 \%$ & e interval & $1.6-10.6$ & & $0.5-2.9$ \\
\hline
\end{tabular}

been outlined by Miettinen (15), along with a method for calculating the confidence interval of the rate ratio (17).

\section{Results}

The study comprised 95 cases, ie, 25 cases of respiratory cancer and 70 cases of cancer in the digestive tract (mouth included), and 370 referents, 10 referents being selected in common for the two series of cases. Table 1 provides a list of the cancer cases constituting both case entities. No case of nasal cancer (ICD 160) appeared in this material, but there were two cases of laryngeal carcinoma (ICD 161) - one a woodworker.

Table 2 shows the distribution of exposure through the occupational titles indicating woodwork among the two series of cancer cases and among the referents. The exposure frequency among the cases of respiratory cancer was $24 \%$ versus $7.6 \%$ among the referents. Among the cases of digestive tract cancer, the frequency of woodworkers amounted to $9 \%$ in comparison with the $7.6 \%$ among the referents. (Note that the two case series were compared with the same referent series.)

For respiratory cancer and woodwork, the crude rate ratio was 3.9 and the Man-
Table 3. Distribution of cases and referents with regard to furniture making, other types of woodwork, and other occupational activity.

\begin{tabular}{|c|c|c|c|}
\hline & $\begin{array}{c}\text { Furniture } \\
\text { makers }\end{array}$ & $\begin{array}{l}\text { Other wood- } \\
\text { workers }\end{array}$ & $\begin{array}{c}\text { Non- } \\
\text { exposed }\end{array}$ \\
\hline $\begin{array}{l}\text { Cases } \\
\text { Referents }\end{array}$ & $\begin{array}{r}4 \\
12\end{array}$ & $\begin{array}{r}2 \\
16\end{array}$ & $\begin{array}{r}19 \\
342\end{array}$ \\
\hline Crude rate ratio & 6.0 & 2.3 & (1.0) \\
\hline
\end{tabular}

tel-Haenszel rate ratio was $4.1(95 \%$ approximate confidence interval 1.6-10.6). Only a slightly increased rate ratio was obtained for the digestive tract, the Mantel-Haenszel estimate being $1.2(95 \%$ approximate confidence interval $0.5-2.9$ ). Since the standard mortality ratio exceeded the crude rate ratio, age tends to be a negative confounding factor. Hence it seems acceptable to use relatively broad age strata, as this procedure can be expected to result in conservative estimates.

Table 3 reflects an attempt to differentiate further between various types of woodwork. The figures of this table suggest that the cancer hazard is mainly related to the furnituremaking industry. Some individuals appearing only as wood- 
workers in the register could have been furniture makers as well.

\section{Discussion}

The results of this study suggest an excess mortality from respiratory cancer among woodworkers, particularly among furniture makers. In view of the earlier reports on nasal cancer among woodworkers, it is not surprising to find an increased incidence of respiratory cancer also outside the nasal cavity. The earlier observed excess of gastrointestinal cancer was not clearly verified in this study, however.

With regard to the control of confounding factors in the study, it has already been indicated that age did not cause any positive confounding effect, as the quotient of the crude rate ratio to the standard mortality ratio was less than unity (16). The smoking habits were not known, but woodworkers are prohibited to smoke at the workplace due to the incurrent fire hazard. Hence it is unlikely that woodworkers should be heavier smokers than the remainder of the population of this town. Moreover, confounding from smoking can hardly explain an observed rate ratio of about 4 as in this study (3), nor are there any other apparent confounding factors which could be blamed for an increased rate ratio of respiratory cancer among these workers. Furthermore, underreporting of occupational titles in the register of deaths and burials would act in a conservative direction.

Although the incidence rate of nasal cancer in general is comparatively high for certain groups of woodworkers, even in this occupational group, the individual risk of dying of nasal cancer is still rather small. In contrast a fourfold increase in the incidence of all respiratory cancers means a considerable individual health hazard for these workers. Further studies are necessary, however, to assess this cancer hazard more definitely in quantitative terms and in view of exposure to various types of wood dust or other agents, eg, lacquers, paint pigments, and molds. Attempts should be made to characterize the dust in quantitative terms and with regard to its origin, ie, type of wood and the generating technical processes, since very little information seems to be available about such aspects of technical hygiene in the woodworking industry.

\section{References}

1. Acheson ED, Cowdell RH, Hadfield E, MacBeth RG. Nasal cancer in woodworkers in the furniture industry. $\mathrm{Br}$ med $\mathrm{j} 2$ (1968) 587-596.

2. Acheson ED, Hadfield EH, MacBeth RG. Carcinoma of the nasal cavity and accessory sinuses in woodworkers. Lancet 1 (1967) 311-312.

3. Axelson O. Aspects on confounding in occupational health epidemiology. Scand $j$ work environ health 4 (1978) 98-102.

4. Axelson $O$. The case-referent (case-control) study in occupational health epidemiology. Scand $\mathrm{j}$ work environ health 5 (1979) $91-99$.

5. Brinton LA, Blot WJ, Stone BJ, Fraumeni JF. A death certificate analysis of nasal cancer among furniture workers in North Carolina. Cancer res 37 (1977) 3473-3474.

6. DeBois JM. Tumoren van de Neusholte bij Houtbewerkers, 1971. Tijdschr Geneeskde 25 (1969) 92-93.

7. DeFaire U, Friberg L, Lorich U, Lundman T. A validation of cause-of-death certification in 1156 deaths. Acta med scand 200 (1976) 223-228.

8. Engzell U, Englund A, Westerholm P. Nasal cancer associated with occupational exposure to organic dust. Acta oto laryngol 86 (1978) $437-442$.

9. Gignoux M, Bernard P. Tumeurs malignes de l'ethmoide chez les travailleurs du bois. $\mathrm{J}$ med Lyon 50 (1969) 731-736.

10. Harrington M, Blot WJ, Hoover RN, Housworth JW, Heath CW Jr, Fraumeni JF Jr. Lung cancer in coastal Georgia: A death certificate analysis of occupation: Brief communication. $J$ natl cancer inst 60 (1978) $295-298$.

11. Ironside $\mathrm{P}$, Matthews $\mathrm{J}$. Adenocarcinoma of the nose and paranasal sinuses in woodworkers in the state of Victoria, Australia. Cancer 36 (1975) 1115-1121.

12. Löbe L-P, Ehrhardt H-P. Das Adenokar zinom der Nase und ihrer Nebenhöhlen eine berufsbedingte Erkrankung bei Beschäftigten in der holzverarbeitenden Industrie? Dtsch Gesundheitswes 33 (1978) 1037-1040.

13. MacBeth R. Malignant disease of the paranasal sinuses. J laryngol otol 79 (1965) $592-612$.

14. Mantel N, Haenszel W. Statistical aspects of the analysis of the data from retrospective studies of disease. $J$ natl cancer inst 32 (1959) 719 -748.

15. Miettinen OS. Standardization of risk ratios. Am j epidemiol 96 (1972) 383-388. 
16. Miettinen OS. Components of the crude risk ratio. Am j epidemiol 96 (1972) 168172.

17. Miettinen OS. Estimability and estimation in case-referent studies. Am $\mathrm{j}$ epidemiol 103 (1976) $226-235$.

Received for publication: 7 May 1980
18. Milham S Jr. Neoplasia in the wood and pulp industry. Ann ny acad sci 271 (1976) $294-300$.

19. Mosbech J, Acheson ED. Nasal cancer in furniture-makers in Denmark. Dan med bull 18 (1971) $34-35$. 